\title{
Abstracts of Papers Presented at the Annual Meeting
}

\author{
SESSION 1A: LOCATION, LOCATION, LOCATION: THE GEOGRAPHY OF \\ INVENTION AND INNOVATION
}

\author{
How Silicon Valley's Skilled Immigrants are Transforming the Geography of \\ Innovation
}

Silicon Valley's high technology economy was created in the 1960s and 1970s by engineers from the east and Midwest of the United States. By 2000 over 40 percent of the region's high-skilled workers were foreign-born, overwhelmingly from Asia. These U.S.-educated immigrant engineers are transforming the geography of innovation as they build technical communities that link Silicon Valley to centers of lower cost skill in their home countries. In a process that is more akin to "brain circulation" than "brain drain," these closely knit networks of engineers and entrepreneurs are transferring technology and know-how between distant regional economies faster and more flexibly than most large corporations. By seeding localized processes of entrepreneurial experimentation in formerly peripheral economies, while maintaining close ties to the technology and markets in Silicon Valley, networks of skilled immigrants in the 1990s created new centers of innovation in Israel and Taiwan. A comparable process is now underway in regions of China and India, with significant long-term consequences for patterns of innovation and economic growth.

ANNALEE SAXENIAN, University of California, Berkeley

The Geography of Invention in High- and Low-Technology Industries: Evidence from the Second Industrial Revolution

Production in "technologically-mature" manufacturing industries has in recent years increasingly relocated from more-developed to less-developed countries with lower costs of labor. It is not clear, however, if these latter countries will realize corresponding increases in their generation of new technological knowledge. More generally, we do not fully understand the sources of geographic clustering in invention, or how prevalent and persistent such clusters are. To investigate these issues, this paper explores the geographic patterns of invention in the shoe, textile and electric industries in the United States during the Second Industrial Revolution. Using both U.S. patent records and information about the inventors drawn from census manuscripts and city directories, I find that in general the location of invention does not appear so directly, or closely, related to the location of production. The intriguing implication is that because individuals with the appropriate knowledge and skills to be effective contributors to new technology are often young and scarce in supply, they will be inclined to migrate to those areas where demand for the technology (and rents to their scarce human capital) is high and resources to support the R\&D are available. The historical evidence appears to suggest that invention and production might not be clustered in the same location. This may be unwelcome news for developing countries that hope to emerge as centers of invention after having attracted shifts in manufacturing capacity from developed countries. 
Do Patents Encourage Knowledge Spillovers? Evidence from the Geographic Location of Innovations at the Crystal Palace

The two primary goals of patent laws are to encourage invention and to diffuse the new knowledge from invention. This paper uses differences in patenting rates across industries to examine whether patenting helps to diffuse technical knowledge, or, in other words, whether patents facilitate knowledge spillovers. Preliminary findings based on the location of 4,465 British exhibits at the Crystal Palace Exhibition in London in 1851 suggest that, in the nineteenth century at least, patents facilitated the spread of new ideas. Innovations in industries with high patenting rates were geographically dispersed, whereas innovations in industries with low patenting rates exhibited strong patterns of geographic concentration, not only within countries, but also within cities.

PETRA Moser, Massachusetts Institute of Technology and NBER

\section{SESSION 1B: LONG-RUN ECONOMIC GROWTH AND INEQUALITY}

Long-Run International Inequality in Human Development and Real Income: Evidence from Europe and the New World

Is inequality cumulating over time? Has the gap between Core and Periphery widened during the last two centuries? For most people, including academics, the answer is yes, even though few systematic attempts have been made to measure it. In this paper an attempt is made to assess intercountry inequality over the nineteenth and twentieth centuries on the basis of income and social welfare indicators for a large sample of Core and Peripheral countries from Europe and the New World for which data on GDP and social indicators of welfare are available. In particular, a new, improved Human Development index is constructed on the basis of new non-income indicators of well-being defined along Kakwani (1993) axiomatic indices, and presented together with new estimates of purchasing power parity adjusted GDP per head. Alternative measures of inequality, including entropy decomposable indices, are provided for real income and human development.

Leandro Prados de la Escosura, Universidad Carlos III, Madrid

The Evolution of Income Concentration in Japan, 1887-2003: Evidence from Income Tax Statistics

This paper presents long-run series of top income shares in Japan between 1887 and 1950 and of top wage income shares between 1951 and 2003, using income tax statistics. Preliminary analysis of the data indicates that the top 1 percent wage income share in Japan has been relatively stable over the postwar years, in contrast to the sharp increase in the top share in the United States after the 1970s. The paper explores the causes of the changes in income concentration from both historical and comparative perspectives. 


\section{Two Centuries of Economic Growth: Europe Chasing the American Frontier}

Starting from the same level of productivity and per-capita income as the United States in the mid-nineteenth century, Europe fell behind steadily to a level of barely half in 1950, and then began a rapid catch-up. While Europe's level of productivity has almost converged, its income per person has leveled off at about three-quarters of America's. How could Europe be so productive yet so poor? The simple answer is that hours per person in Europe have fallen drastically in the past 40 years, reflecting long vacations, high unemployment, and low labor force participation, and only about onethird of the Europe-America difference reflects voluntarily chosen leisure. A historical analysis traces Europe's falling behind after 1870 to American political unity, fostering large-scale material-intensive manufacturing and a set of marketing innovations, and after 1913 to the early American exploitation of the great inventions of electricity and the internal combustion engine, while Europe was distracted by wars. After 1950 Europe's catch up was achieved both by exploiting the great inventions 40 years late, and also by the gradual erosion of early American advantages. But after 1995 the gap began to widen again, a development that brings to the forefront fundamental American advantages in fostering and exploiting innovation.

ROBERT GORDON, Northwestern and NBER

\section{SESSION 2A: GOVERNMENT POLICY TOWARDS INNOVATION}

\section{Equilibrium Impotence: Why the States and not the American National Government}

Building a national transportation system was a central link in the development of the nineteenth-century American economy. Despite calls for national improvements, the federal government spent nearly an order of magnitude less on transportation projects between 1790 and 1860 than did state and local governments. This paper develops a general political economy model of a democratic legislature faced with the problem of financing a large transportation investment that serves a minority of the geographic units represented in the legislature - states in the federal case. We show that three alternative financing schemes can command majority support and leave no district worse off, and that the federal government was only able to use two of three methods because of constitutional restrictions on taxation. We show that 97 percent of all federal transportation expenditures followed the two schemes, and that the federal government most often used a method of finance suited for small local projects rather than interregional projects. We complete the argument, by comparing the state experience. States were able to tailor taxes to suit political constraints. As a consequence, states built most of the largest and most important inter-regional transportation links in the antebellum era.

JOHN WALLIS, Maryland AND BARRY WEINGAST, Stanford

\section{Antitrust and Innovation Policy in Early Cold War America}

This paper examines the influence of antitrust policy upon technological change in two American industries - computing and paper, during the decades following World War II. It combines detailed examination of key antitrust prosecutions with thorough 
case studies of firm behavior based on records in corporate archives. The paper focuses upon both the theory and the practice of antitrust. By examining developments in two widely divergent industries, it attempts to elucidate whether the Department of Justice acted upon a comprehensive theoretical understanding of the relationship between competition, market structure, and technical change. The paper then investigates whether antitrust activities significantly altered firm behavior regarding technical change, whether any changes in firm behavior followed paths anticipated by the Department of Justice, and whether altered firm behavior ultimately influenced the course of technical change in significant ways.

Steve Usselman, Georgia Institute of Technology

\section{SESSION 2B: SOCIAL WELFARE IN VICTORIAN BRITAIN}

\section{Poverty among the Elderly in Victorian Britain}

Despite the sharp increase in wage rates for manual workers from 1850 to 1914, poverty rates among the elderly remained high in Victorian Britain, although the extent of pauperism varied significantly across Poor Law Unions. This paper begins by examining the ability of workers to provide for their old age through saving and membership in friendly societies. We construct a data set consisting of information for all 586 English Poor Law Unions for 1891/2. We estimate regression equations to explain variations across unions in the extent of pauperism, and test several conjectures made by contemporaries and repeated by historians. For example, what effect did the substitution of workhouses for outdoor relief have on the number of elderly paupers? We then examine the implications of our results for the debate over national old-age pensions which occurred from the 1890s until the adoption of the Old Age Pension Act in 1908.

\section{GEORGE BOYER, Cornell AND TIMOTHY SCHMIDLE, Cornell}

\section{The Economic Return to Primary Schooling in Victorian England}

In this paper, I use longitudinal data on individual males linked between the English censuses of 1851 and 1881 to examine the effect of childhood primary school attendance on adult socioeconomic status in Victorian England. Primary schooling was not compulsory, nor was it state provided. Primary education was a choice made by parents for their children. The panel nature of the data allows both the schooling decision and the effect of that decision on the individual's adult labor market outcome to be analyzed. A structural model of rational school choice indicates that parents were responsive to the anticipated future economic effect of the schooling on their children. For individuals from all socioeconomic backgrounds who received primary schooling, the benefits were substantial. 


\title{
SESSION 3A: COLLECTIVE INSTITUTIONS AND COLLECTIVE INVENTION
}

\author{
Craft Guilds and Property Rights to Technical Knowledge in Premodern Europe, \\ c. $1300-c .1800$
}

The role of technology in the transition from premodern, "Malthusian," to modern economies in late eighteenth- and nineteenth-century Europe is among the major questions in economic history, but it is still poorly understood. In particular, the view that premodern societies experienced low labor productivity and stagnant living standards, which suggests that technological change before c. 1800 was close to zero due to pervasive guild rent seeking and poorly specified property rights to knowledge is hard to square with the fact that the surge of technological innovation in the eighteenth century occurred within institutional frameworks not too dissimilar to those of 1300. It is well known that the technical knowledge of premodern craftsmen and engineers was largely experience-based, or experiential. However, the implications of the fact that there were basic cognitive limitations to how technical knowledge could be expressed, processed and transmitted have yet to be examined in detail. The paper elaborates on this point, spells out the main implications for property rights to knowledge, and suggests that the principal, endogenous bottleneck to premodern technical diffusion and innovation was the cost of person-to-person teaching and demonstration.

S. R. EPSTEIN, London School of Economics

\section{Medieval Guilds Redux: Contemporary Institutions for Collective Invention}

This essay draws on recent scholarship concerning the nature and function of medieval guilds. I argue that certain features of these guilds appear in modern institutions that further collective invention: patent pools, industry-wide standard-setting organizations, informal knowledge exchange among academic scientists, and (in a more limited way) open source software development . In particular, guilds and modern institutions share three features: an "appropriability structure" that makes it profitable for individual entities to both develop new technologies and share them; reliance on group norms, as opposed to formal legal enactments, as an enforcement mechanism; and a balance of competition and cooperation under which group-generic information is shared, but individual-proprietary information is not. Collective invention institutions demonstrate that formal property rights are not the only way to foster innovation and that mediating institutions may mitigate property-rights bottlenecks, lessening what has been termed the "tragedy of the anticommons."

ROBERT MERGES, University of California, Berkeley

Patronage, Reputation, and Common Agency Contracting in the Scientific Revolution: The Historical Origins of "Open Science" Institutions

The emergence during the late sixteenth and early seventeenth centuries of the idea and practice of "open science" was a distinctive and vital organizational aspect of the Scientific Revolution. In contrast to the previously dominant ethos of secrecy in the pursuit of Nature's Secrets, a new set of norms, incentives, and organizational structures reinforced scientific researchers' commitments to rapid disclosure of new knowledge. The appearance of "cooperative rivalries" in revealing new knowledge were a functional response to heightened asymmetric information problems encoun- 
tered by the Renaissance system of court-patronage of the arts and sciences, created by the increasing practical reliance upon new mathematical techniques in a variety of "contexts of application." Fragmented political authority gave rise to relations between noble patrons and savant-clients that resembled the situation economists describe as "common agency contracting in substitutes," thereby promoting more favorable contract terms for the agent client members of Europe's nascent scientific communities.

PAul DAVID, Stanford

SESSION 3B: GOVERNMENTS POLICY TOWARDS INNOVATION

\section{Capital Deepening in American Manufacturing, 1850-1880}

We use establishment-level data to study capital deepening-increases in the capital-output ratio - in American manufacturing from 1850 to 1880 . In nominal terms, the aggregate capital-output ratio in our samples rose by 30 percent from 1850 to 1880 . Growth in real terms was considerably greater -70 percent-because prices of capital goods declined relative to output prices. Cross-sectional regressions suggest that capital deepening was especially important in the larger firms and was positively associated with the diffusion of steam-powered machinery. However, even after accounting for shifts over time in such factors, much of the capital deepening remains to be explained. Although capital deepening implies a fall in the average product of capital it does not necessarily imply that rates of return were declining. However, we find strong evidence that returns did decline. We also show that returns were decreasing in firm size, although the data are not sufficiently informative to tell us why it was so.

\section{JEREMY ATACK, Vanderbilt and NBER, FRED BATEMAN, Georgia, AND ROBERT MARGO, Vanderbilt and NBER}

Industrialization and Urbanization: The U.S. Experience, 1820-1920

The U.S. went from an agricultural to an industrial nation between the early nineteenth and the turn of the twentieth centuries. In the seventeenth century, manufactured goods were produced by artisans and households, or were imported from England. However, beginning in the early nineteenth century, manufactured goods were increasingly produced in factories, especially in New England. As the century progressed, manufacturing grew and spread to the Middle Atlantic and became concentrated in the northern region of the United States, forming a manufacturing belt. This paper explores the linkages between industrialization and urbanization. Whereas early industrialization was associated with growth of manufacturing in rural areas, late industrialization was significantly correlated with the growth of manufacturing in urban areas. This paper constructs data on U.S. cities and counties for the period between 1820 and 1920 and examines the various theories of industrialization and urbanization. 
The Industrial Revolution in the Prewar Lower Yangzi Region of China

This article utilizes a GDP framework to make an assessment of economic growth and change in China's most advanced region, the Lower Yangzi, from the early modern period to the present It offers a quantitative assessment of the Shanghai-based industrialization in the first three decades of the twentieth century through a detailed compilation of a 1933 Lower Yangzi GDP. It shows that the Lower Yangzi in the 1930s had a per capita GDP 64 percent higher than China's national average, and experienced a magnitude of growth and structural change between 1914-1918 and 19311936 comparable to that of Japan and her East Asian colonies during this period. This paper further provides a historical narrative arguing that the city-state model adopted in early-twentieth-century Shanghai, with its secure property rights and provision of public goods, laid the institutional foundation of an Industrial Revolution in the Lower Yangzi with long-lasting political and economic impact across East Asia.

DEBIN MA, National Graduate Institute for Policy Studies, Japan

\section{SESSION 4A: CHALK AND TALK: SCIENCE, ACADEMIA, AND INNOVATION}

Why did U.S. Universities begin Patenting and Licensing during the 1970s?

A number of scholars have documented the role of the 1980 Bayh-Dole Act in the growth of patenting and licensing by universities since 1980 (Henderson et al., 1998). But Bayh-Dole is properly viewed as initiating the latest, rather than the first, phase in the history of U.S. university patenting. Relatively few universities managed their patent portfolios themselves during the 1925-1970 period, but this situation began to change during the 1970s. This paper reviews the causes of increased entry by universities into direct management of patenting and licensing, as well as the factors underpinning the growth in private universities' role as patenters and licensors, during the 1970 s. We draw on a database on university patents covering the 1948-80 period, as well as data on "Institutional Patent Agreements" between universities and federal agencies responsible for the bulk of academic research funding, in an analysis of the determinants of entry and the "governance" of licensing under the terms of IPAs.

DAVID MOWREY, University of California, Berkeley AND BHAVEN SAMPAT, Georgia Institute of Technology

\section{Academic Science and the Growth of Industrial Research}

This paper argues that the unique form taken by American universities in the late nineteenth and early twentieth centuries helped promote the adoption of industrial research laboratories in nearby firms. Proximity to academic science reduced the costs faced by firms establishing research labs - by easing communication with academic consultants and facilitating the hiring of university-trained scientists - and as a result the early industrial research laboratories benefited by locating close to universities. This paper explores the link between the blossoming of American higher education and the growth of industrial research, taking a two-pronged approach to the research question. First, it tests whether the early industrial research labs were more likely to be located near universities. It finds that the number of industrial research labs in a county in a given year is significantly related to the number of universities and the ex- 
tent of university spending on research. However, for a firm-level subsample consisting of firms in the chemical industry, proximity to academic science is found to matter only for young firms. Industrial research laboratories established before the expansion of higher education in the late nineteenth and early twentieth centuries are not more likely to be found near universities. Secondly, the paper tests for evidence of spillovers arising from university research.

Megan MACGARVIE, $B U$

\section{The Evolution of Biological Resource Centers}

Biological resource centers (BRCs) are "living libraries" that authenticate, preserve, and offer independent access to biological materials, such as cells, cultures, and specimens. This paper explores the role that such institutions played within the life sciences over the last century. The history of biomaterials exchange highlights the key challenges in ensuring the integrity of the research process and the role of collective institutions in addressing those challenges. Understanding how institutions impact the degree of confidence in research materials and the implications for overall research productivity requires a paradigm for assessing the role of institutions in cumulative progress. From the perspective of the economics of science and technological change, BRCs offer an important case study of the importance and requirements for step-bystep scientific and technological progress, and the impact of institutions on the process of cumulative knowledge production.

SCOTT STERN, Northwestern and NBER

\section{SESSION 4B: THE THREE DONS: THE VIEW FROM THE SPIRES OF OXFORD}

\section{Labor Productivity in Arable Agriculture around the World, 1700-1870}

We introduce a large, new data set on agricultural output and employment in the wheat-producing areas of the world between 1700 and 1870. Using these data, we present new estimates of labor productivity in arable agriculture around the world. Output per worker varied wildly across countries, with Western Europe and North America generally having substantially higher output per worker than India and China. Most of the variation in output per worker within Western Europe and North America was due to variations in output per acre (i.e., acres per worker were similar across western countries). But the labor productivity differential between North America and Europe on the one hand, and India and China on the other, was a result of a massive differential in acres per worker.

LIAM BRUNT, Oxford

\section{The Nitrogen Hypothesis and the English Agricultural Revolution: A Biological Approach}

This paper uses a science-based model of nitrogen in agriculture to gauge the contributions of animal manure, peas, beans, clover, and convertible husbandry to crop yields from 1300 to 1800 . Medieval yields were not depressed by a deficiency of animals in so far as they recycled nitrogen on the arable. The cultivation of peas, beans, 
and clover introduced enough nitrogen into farming to account for half of the rise in crop yields, while convertible husbandry could explain even more. Convertible husbandry was important in raising yields in the sixteenth century, but its advantage waned as the cultivation of legumes spread in the seventeenth. Changes in population explain why these improvements were not adopted in the middle ages but later became profitable.

RoBert AlLEN, Nuffield College

\title{
The North Atlantic Meat Trade and its Institutional Consequences
}

Expansion of the international grain market has been extensively studied, but the trade in meat and meat animals is relatively poorly explored. This is all the more surprising because by the eve of the First World War, it was of nearly comparable value to the grain trade. The meat trade bore considerable resemblance to the grain trade, but differences are at least as striking. Lower transportation costs and increased demand drove the developments as they did in grain. However, the impact of new technology cannot be simply summarized in terms of much lower freight rates. Long distance trade in meat inexorably altered conditions of meat supply and was tied to the evolution of new wholesale and retail distribution of fresh meat. Major changes in industrial organization emerged. With the new distribution came larger firms and greater vertical integration in both meat distribution and in transportation. In meatpacking and distribution, American firms emerged dominant in both exporting and importing regions. In ocean shipping, liner companies transported the cattle and meat.

KNICK HARLEY, Oxford

\section{SESSION 5A: FIRMS AND INVENTORS IN THE NINETEENTH AND TWENTIETH CENTURIES}

\author{
The Decline of the Independent Inventor: A Schumpeterian Story?
}

Joseph Schumpeter argued in Capitalism, Socialism and Democracy that the rise of large firms' investments in in-house R\&D spelled the doom of the entrepreneur. We explore this idea by analyzing the career patterns of three cohorts of inventors from the late nineteenth and early twentieth century. We find that over time highly productive inventors were increasingly likely to form long-term attachments with firms. In the Northeast, these attachments seem to have taken the form of employment positions within large firms, but in the Midwest inventors were more likely to become principals in firms bearing their names. Entrepreneurship, therefore, was by no means dead, but the increasing capital requirements - both financial and human - for effective invention and the need for inventors to establish a reputation before they could attract support made it more difficult for creative people to pursue careers as inventors. The relative numbers of highly productive inventors in the population correspondingly decreased, as did patenting rates per capita.

NAOMI LAMOREAUX, University of California, Los Angeles and NBER AND KENNETH SOKOLOFF, University of California, Los Angeles and NBER 
Patents and Technological Competencies: A Cross National Study of Intellectual Property Right Strategies in the Synthetic Dye Industry, 1857-1914

The dramatic increase of firm patenting in the United States during the last two decades may give the impression that the acquisition of patents is becoming increasingly important for protecting and leveraging technological competencies. A historical perspective on how firms acquire technological competencies and leverage them in different markets reveals, however, that it is far from obvious that the possession of patents will lead to long-tern competitive success. German and Swiss firms in the early years of the synthetic dye industry created superior technological competencies than their British and French counterparts precisely because they were initially unable to obtain patent monopolies in their home markets. Analyzing the history of the synthetic dye industry from 1857-1914 in a variety if countries, the purpose of this paper is to contribute to a more nuanced understanding of the role of patents in the development of firm capabilities.

JoHANn Peter MurmanN, Northwestern

Technology, Investment, Finance and Performance in the Second Industrial Revolution

In recent research on the relationship between finance and growth, there has been growing attention to heterogeneity across industries in their dependence on the financial system and the benefits that they derive from it. Various hypotheses have been advanced about the financial demands of different industries and their determinants. However, a dearth of evidence on the patterns of finance across industries and their relationship to technology, investment, and performance has hampered progress on the topic. My paper will analyze the role of finance in three prominent industries in the United States - electrical equipment, chemicals, and automobiles - for the period from 1890 to 1929. All three of these industries played a prominent role in the Second Industrial Revolution. During the period covered by my study, they experienced high levels of technological change and innovation, an increase in their capital requirements and a rapid growth in their output. Company-level data will be used as the basis for a quantitative analysis of investment, finance, and performance in these industries. It will be complemented with qualitative discussions of technological change, competitive structure and organizational characteristics in these industries.

MARY O'SULLIVAN, INSEAD

\section{SESSION 5B: FINANCIAL MARKETS AND INSTITUTIONS}

\section{Related Lending and Economic Performance: Evidence from Mexico}

There is a broad consensus that bankers in LDCs engage in related (insider) lending. There is not, however, a consensus as to whether related lending has a positive or negative effect on economic growth. We argue that related lending has negative consequences for growth compared to the outcome that would obtain in an efficient capital market because bankers choose borrowers based on personal contacts rather than the quality of the underlying projects. The result is the misallocation of capital. We also argue that related lending arises as a rational response to high levels of default 
risk. Thus, it is an endogenous outcome of weak property rights or information asymmetries that are costly to overcome. In sum, related lending is a second-best outcome, but it is superior to the readily available alternative: banking systems that effectively do not lend at all for productive purposes.

NOEL MAURER, ITAM AND STEPHEN HABER, Stanford

\section{The Development of the Paris Bourse in the Interwar Period}

In this paper, we present a new database on the French Bourse during the interwar period, which should enable a much more thorough research on the functioning and development process of that market. This database includes for every listed security monthly prices, earnings, splits, and other capital operations, issues, and, most importantly, a measure of liquidity. Using this database, we first present a few stylized facts on the development of the Parisian capital market during the interwar period. We discuss the limitations of earlier indices and build a new stock index which, being better constructed and restricted to blue chip firms, is more easily comparable to foreign indices of the same period. This new index modifies the standard view of the Paris market in the interwar period, showing for example that the price growth was higher than previously thought during the 1920 s and that the decline in the stock prices started earlier than in New York.

Pierre-Cyrille Hautcoeur, ENS, Paris AND Muriel Petit-KonCZYK, Lille, ESA

\section{Contractual Responses to Institutional Changes: A Historical Institutional Analysis}

This paper uses historical records and economic theory to investigate the combined institutional and contractual arrangements that facilitated long-distance trade in late medieval Venice. Institutional changes that enhanced the State's ability to verify information led the transition from the sea loan (a debt-like contract) to the commenda (an equity-like contract) and enabled a better allocation of risk. These institutional developments also lessened the merchants' opportunities to influence the ventures' outcome through their choice of action/effort, thereby mitigating moral hazard problems with respect to project choice and effort. The Venetians, instead of designing contracts to economize on agency costs, developed better institutional arrangements.

YADIRA GONZALEZ DE LARA, Alicante

\section{PLENARY SESSION 6: ENDOGENOUS GROWTH, SCIENCE, AND ECONOMIC HISTORY}

\section{Growth Theory, Economic History, and the Arc of Science}

We achieve our most complete understanding of any phenomenon when our conversations follow an arced trajectory that starts from a specific context, moves up to higher levels of abstraction, and then returns back to a (possibly different) specific context. Economic theorists in general, and growth theorists in particular, focus much of their energy on the ascending portion of the arc. They are skilled at stripping the 
context from a conversation and translating it into the abstract language of mathematics. But the real test of their efforts comes in the return back down to the kind of context that economic historians examine, contexts in which countries, firms, sometimes even people, have names. Examples drawn from economics and other disciplines suggest that a good indicator of a successful return is a change in how we use natural language. In the end, new words and phrases or sharpened understandings of existing ones may be some of our most important research outputs.

PAUL ROMER, Stanford

Endogenous Changes in 20th Century America

NATHAN RosenBerg, Stanford

\section{SESSION 7A: INSTITUTIONS AND NATURAL RESOURCES IN THE AMERICAN WEST}

Transaction Costs and Resistance to Water Rights Transfers: The Legacy and Lessons of the Owens Valley Transfer to Los Angeles

The completion of the Los Angeles Aqueduct from Owens Valley in 1917 brought an important new source of water to the city. Indeed, with Owens Valley water, Los Angeles grew from 250,000 people in 1905 to over 2,000,000 in 1930. Today, Owens Valley water accounts for approximately 60 percent of Los Angeles's water. The water transfer was the first, one of the largest, and the most controversial rural-to-urban water transfer in the United States. Because it is presented as all that can go wrong with water transfers, it figures prominently and negatively in all efforts to promote a re-allocation of water in the semi-arid West today. This paper examines the transfer process and negotiations between the city and land owners in the Owens Valley. Between 1905 and 1935 Los Angeles purchased virtually all of the private property in the valley. It would seem that because Los Angeles purchased the land and internalized the externalities involved, the episode should have been a success story instead of one that complicates current transfer efforts. Instead, the negotiations were acrimonious, and periodically violence erupted leading to dynamiting of part of the Los Angeles aqueduct, one of the country's largest public works projects up to that time. This paper examines the sources of the disputes over price and why they were so difficult to resolve. It also presents the likely economic history of agriculture in the valley had irrigation continued to evaluate the often-claimed assertion that the water transfer destroyed a vibrant agricultural economy, leaving instead, a desert.

GARY LIBECAP, Arizona and NBER

The Evolution of Irrigation Institutions in California: The Rise of the Irrigation District, $1910-1930$

This paper addresses the phenomenon of the dramatic decline of private irrigation institutions and the corresponding rise of public irrigation institutions in early twentieth-century California. The existing literature presents explanations of this transformation that view public irrigation organizations either as solutions to market failure or primarily as a mechanism for the redistribution of income. An alternative explanation 
is set forth in this paper. This explanation maintains that the rise of the public irrigation district was the result of a complex interaction of agricultural, regulatory, and legal changes during the early years of the twentieth century. As large farm holdings were increasingly subdivided and sold during the nineteenth and early twentieth centuries, and the with imposition of water rate regulation in 1912 and the growing political influence of water users, it became increasingly difficult for private irrigation companies (which were commonly joint land-water development enterprises that relied upon land sales, not water sales, to turn a profit) to capture a sufficient share of the benefits of new, large-scale irrigation projects to make them privately profitable. The rising social rates of return on irrigation investment after 1910, coupled with the failure of private water companies to realize these gains, led to a demand for organizations which could appropriate these benefits. This in turn led to key legislation in 1911 and 1913 which greatly enhanced the organizational advantages of the public irrigation district. Primary data collected from irrigation districts and contemporary newspapers, as well as data from published state and federal sources, provide support for this hypothesis.

EdWARD MCDEvitT, California State, Northridge

\section{Why Would Order Without Law Result in First Possession? Water Rights During the California Gold Rush}

Economists and legal scholars have long been intrigued by the question of why orderly resource allocation often occurs in the absence of formal laws that define and enforce property rights, a phenomenon dubbed Order Without Law by Robert Ellickson. Ellicksom debunks the persistent misconception that formal law is all that matters but contains few specific predictions regarding the property rights arrangements likely to emerge from a situation lacking formal laws. This paper examines the emergence of the legal principle of first possession from just such a situation: the mining camps of the early California Gold Rush. Despite the absence of formal controlling law, the mining camps set in place orderly procedures for acquiring, maintaining, and alienating water rights, but varied dramatically in their reliance on first possession. This fact permits us to gain insights into the factors that influence the adoption of first possession by private agents under democratic conditions essentially unconstrained by controlling legal precepts.

Mark KanaZawa, Carleton College

\section{SESSION 7B: THE STARBUCK SESSION: SAILING, WHALING AND STEAMSHIPS}

\section{Was the Shift from Sail to Steam in Ocean Shipping, 1860 to 1912, Skill-Biased?}

This paper examines the extent of skill bias associated with the shift from sail to steam technology in ocean shipping between 1860 and 1912. It employs a data set of merchant seamen crew agreements to compare occupational distributions and wages between skilled and unskilled workers on sail versus steam crews over this period. It also estimates the wage premium to literacy and the age-wage profile for merchant seamen under both technologies. Many contemporary accounts suggested that the shift from sail to steam technology was deskilling and resulted in a general deterioration of seamanship. In contrast, the results here suggest by some measures that the shift from sail to steam was skill-biased although this result depends on how skill bias is meas- 
ured. The study thus documents a significant late-nineteenth-century episode of the changing relationship between technology and skills.

DAVID MiTCH, Maryland

Incentives and Productivity in Corporations: Evidence from the American Whaling Industry

The use of incorporation contributed to the development of many nineteenthcentury industries, but whaling was not one of them. Of the whaling ventures that received corporate charters in the $1830 \mathrm{~s}$, none survived for more than nine years, at a time when unincorporated whaling ventures enjoyed growing success. This paper analyzes the historical origins of the contracts and organizational forms employed in the American whaling industry, and examines their development in response to moral hazard problems. Most whaling ventures were owned by a small number of investors, and were configured to provide powerful incentives. The corporate form of ownership, as implemented in the 1830s, was incapable of providing the incentives requisite for success in whaling. The analysis of a newly collected panel of more than 800 whaling voyages from 17 different ports supports the main conclusions of the paper.

ERIC HILT, Wellesley

\section{Steamship Competition and Nineteenth Century Immigration}

The behavior of the major transatlantic passenger steamship companies is investigated during the third quarter of the nineteenth century. This time period saw the steamship replace the sailing ship, a large decline and then large increase in immigrant volume, rapid changes in the technology of the steamship, and, in contrast to later years, competition among the various companies. Data on each passenger steamship arriving at New York City are gathered from the U.S. Passenger Lists for every third year beginning in 1852 and continuing through 1876 (thus, for nine different years). In sum, the data set contains information on 2,864 voyages undertaken by 306 ships operated by 36 different companies. The paper presents empirical information on the market shares of the major companies, investigates the reasons for the changing shares, and examines the competitive behavior of the steamship companies and market in a variety of ways.

RAYMOND COHN, Illinois State

\section{SESSION 8A: THE SPREAD OF INNOVATIONS: DIFFUSION AND RESISTANCE}

\section{The Diffusion of the Steam Engine in Eighteenth-Century Britain}

In this paper we concentrate on the diffusion of steam technology across British counties during the eighteenth century. Following a rather established approach for analyzing the diffusion of new technologies, we fit logistic growth functions to the data on the numbers of steam engines erected in each county. Afterwards, in order to assess the factors influencing the diffusion of steam power technology, we estimate "adoption equations" relating the number of steam engines erected in each county with a number of localization factors such as coal prices, availability of water sites, number 
of textile mills and number of blast furnaces. In this way, we are able to provide a thorough reconstruction of regional variations in the timing, pace and extent of usage of steam engines. Our analysis sheds some new light on the different adoption patterns characterizing the diffusion of Newcomen and Watt engines.

\title{
ALESSANDRO NUVOLARI, Eindhoven University of Technology, B. VERSPAGEN, Eindhoven University of Technology, AND N. von TunZELMAnN, Sussex
}

Farmer Resistance to the Tuberculin-Testing Program to Eradicate Bovine Tuberculosis in the United States, 1893-1941

A recurrent theme in the economic and technological history literatures is the importance of active opposition to technical change. This paper examines the concrete example of widespread farmer resistance during the early twentieth century to government-led campaigns to use new tuberculin-testing technologies to eradicate bovine tuberculosis in the United States. Drawing on newspaper sources and the archival records of the Bureau of Animal Industry, we explore four issues: the political economy of opposition; the role of earlier scientific controversies in the discourse of the opposition movement; the techniques including radio and litigation used by the opponents; and finally international comparisons.

\section{Alan OlMSTEAD, University of California, Davis AND PAUL RHODE, University of North Carolina and NBER}

\section{Diffusion of the Cotton-Picking Machine, 1949-1964}

Within a 20 -year period after 1949 , mechanical cotton harvesting in the United States replaced what for centuries had been a hand operation. This innovation, perhaps even more than others in American agriculture had enormous implications for the society into which it was introduced, including the disappearance of the South as a separate region in the United States, the Civil Rights movement, the rural-urban migration of African-Americans, racial economic equality, and the demise of America's cities. Despite recent progress in understanding the labor market dynamics involved, the diffusion of the mechanical cotton picker itself remains incompletely understood, especially its striking west-to-east pattern. Here with newly constructed hand-to-machine harvest cost data, we estimate the diffusion of the mechanical cotton harvester with a two equation model. We find diffusion resulted from the rapid decline in the costs of mechanical cotton harvesting due to local (cotton yields) and exogenous improvements in technology (productivity gains in manufacturing and distribution exogenous to the mechanization of the cotton harvest itself).

WAYNE GRove, LeMoyne College AND CRAig HeInICKe, Baldwin-Wallace College

\section{SESSION 8B: PRODUCTIVITY IN EUROPE AND THE UNITED STATES}

\author{
Interwar Multifactor Productivity Growth in the United States
}

Multifactor productivity growth in the private nonfarm economy in the United States was 2.12 percent per year (continuously compounded) between 1919 and 1929 
and 2.31 percent per year between 1929 and 1941. In both periods MFP growth in manufacturing was exceptional: 5.12 percent (1919-1929) falling to 2.91 percent between 1929 and 1941. If MFP growth in manufacturing was lower, how did the 19291941 years end up yielding a higher rate of MFP growth than did the 1920s? The answer appears to lie in a very high rate of MFP growth in transport and public utilities (4.67 percent per year), combined with moderate growth in wholesale and retail distribution, which preliminary estimates place at about 1.81 percent per year. In comparison, I estimate MFP growth in transport and public utilities at only 1.86 percent per year between 1919-1929, and wholesale and retail distribution, at only about 0.8 percent per year.

Alex Field, Santa Clara

TFP, Social Savings and the Consumer Surplus of the Film Industry, 1900-1938

This paper estimates and compares the benefits cinema technology generated to society in Britain, France, and the United States between 1900 and 1938. It is shown how cinema industrialized live entertainment, by standardization, automation, and making it tradable. The economic impact is measured in three ways: TFP-growth, social savings in 1938 and the consumer surplus enjoyed in 1938. Preliminary findings suggest that the entertainment industry accounted for 1.5 to 1.7 percent of national TFP-growth and for 0.9 to 1.6 percent of real GDP-growth in the three countries. Social savings were highest in the United States (c. 2.5 billion dollars and three million workers) and relatively modest in Britain and France, possibly because of the relative abundance of skilled live-entertainment workers. Converging exchange rates and PPP price ratios suggest rapid international market integration. The paper's methodology and findings may give insight in technological change in other service industries that were also industrialized.

GERBEN BAKKER, Essex

Benchmark Estimates of UK/US Sectoral Productivity, 1870-1950

Two competing views of relative UK/US labor productivity since 1870 have recently emerged in the literature. Ward and Devereux (2003) provide expenditurebased benchmark comparisons of UK/US productivity. Broadberry $(1997,1998)$ provides productivity comparisons based on UK/US sectoral output. Whereas the Ward and Devereux comparisons are based on a direct comparison of prices and expenditures in each benchmark year, Broadberry's $(1997,1998)$ comparisons are to a large extent derived from time series extrapolations. The direct comparisons show the United States leading the United Kingdom as early as 1870 but the sectoral comparisons suggest that the United States does not pass the United Kingdom until the turn of the twentieth century. In this paper, we reconcile the evidence on UK/US sectoral productivity with the direct, expenditure based estimates of overall productivity. 